\title{
PENERAPAN PROGRAM KOTAKU DALAM MENGATASI KAWASAN PERMUKIMAN KUMUH DI KAMPUNG RAWA BARAT, KELURAHAN KEBON JERUK, KOTA JAKARTA BARAT
}

\author{
Tika Amelia Karina ${ }^{1)}$, Parino Rahardjo2), Jo Santoso ${ }^{3)}$ \\ 1)Program Studi S1 PWK, Fakultas Teknik, Universitas Tarumanagara, tikaharahap98@gmail.com \\ 2)Program Studi S1 PWK, Fakultas Teknik, Universitas Tarumanagara, parinor19@gmail.com \\ 3)Program Studi S1 PWK, Fakultas Teknik, Universitas Tarumanagara, josantosojkt@gmail.com
}

\begin{abstract}
Abstrak
Program KOTAKU adalah program strategis pemerintah yang memiliki tujuan untuk meningkatkan infrastruktur dan pelayanan dasar pada kawasan permukiman kumuh perkotaan. Kampung Rawa Barat merupakan salah satu kampung kota yang mendapat prioritas pelaksanaan program KOTAKU, hal ini ditunjukkan pada daftar Kampung Kumuh dan juga Lokasi TORA Prioritas Kegiatan Reforma Agraria Provinsi DKI Jakarta. Terdapat 3,7 hektar kawasan kumuh di Kampung Rawa Barat dengan berbagai macam permasalahan. Permasalahan yang ada di dalam kawasan kumuh ditunjukkan dengan kondisi eksisting sarana dan prasarana dasar yang belum sepenuhnya terlayani serta memadai. Tujuan penelitian ini adalah untuk menganalisis karakteristik masyarakat responden, kondisi fisik perumahan dan permukiman kumuh, tingkat kekumuhan kawasan permukiman dan tingkat partisipasi masyarakat yang tinggal pada kawasan permukiman kumuh. Metode analisis yang digunakan yaitu menggunakan pendekatan kuantitatif. Sumber data yang digunakan terdiri dari 2 jenis yaitu data primer dan sekunder. Jumlah responden penelitian sebanyak 88 responden dari total 2 RT (RT15/16). Hasil penelitian ini menunjukkan bahwa penduduk yang tinggal di kawasan permukiman kumuh mayoritas berjenis kelamin laki-laki golongan usia muda, dengan pekerjaan PKL serta berpenghasilan rata-rata dibawah 1 juta rupiah, dan mayoritas penduduk lebih didominasi oleh penduduk asli. Selain itu untuk kondisi fisik kawasan permukiman kumuh menunjukkan adanya bangunan hunian yang tidak layak huni, permukiman yang jalan lingkungannya belum sesuai standar teknis, sampah masih dibunag secara sembarangan di beberapa titik, dan masih banyak rumah yang belum terlayani saluran pipa septik atau tanki septiktank. Tingkat kekumuhan pada Kampung Rawa Barat berada pada tingkat kekumuhan Ringan. Sementara tingkat partisipasi dalam penyelenggaraan program KOTAKU di Kampung Rawa Barat berada pada tingkat partisipasi Sedang.
\end{abstract}

Kata Kunci: Program KOTAKU; Partisipasi Masyarakat; Tingkat Kekumuhan.

\begin{abstract}
KOTAKU is government's strategic program which intended to increase to basic infrastructure and service in slum areas. Kampung Rawa Barat is one of the towns which gets the priority in the implementation of KOTAKU program and the TORA location priority for Agrarian Reform Activities There are 3.7 hectares of slum area in Kampung Rawa Barat with various problems such as the condition of facilities and infrastructure, with indications of various problems besides that there are also 32 houses in Kampung Rawa Barat whose buildings stand on the banks of rivers. The problems that exist in slum areas are indicated by the existing conditions of basic facilities and infrastructure that have not been fully served and adequate. The purpose of this study was to analyze the respondents, the physical condition of housing and the community, the level of slums, the area, and the participation of the people living in this tourist area. The analytical method used is using a quantitative approach. The data sources used consist of 2 types, namely primary and secondary data. The number of research respondents was 88 respondents from a total of $2 R T(R T 15 / 16)$. The results of this study indicate that the majority of the population living in slum areas are young men, working street vendors and earning an average of less than 1 million rupiah, and the majority of the population is
\end{abstract}


dominated by natives. In addition, the physical condition of slum areas shows that there are residential buildings that are not suitable for habitation, settlements whose environmental roads do not meet technical standards, waste is still disposed of carelessly at several points, and there are still many houses that have not been served by septic pipes or septic tanks. The level of slums in the slum area in Kampung Rawa Barat is at the level of light slums. Meanwhile, the level of participation in the implementation of the KOTAKU program in Kampung Rawa Barat is at a moderate level of participation.

Keywords: KOTAKU Program; Level of Dinginess; People's Participation.

\section{PENDAHULUAN}

\section{Latar Belakang}

Permukiman kumuh perkotaan adalah hal yang unik dengan segala problematika sosialnya seperti tidak terjaminnya kualitas hidup yang layak sehingga masalah seperti kesehatan bahkan kebersihan adalah hal yang mudah di temukan. Di dalam permukiman kumuh biasanya di ikuti dengan pola gaya hidup yang tidak tertib seperti pendirian bangunan liar disekitar bantaran sungai dan di sekitaran rel kereta api, membuang sampah sembarangan yang berdampak mencemari lingkungan. Karena itu, masalah perkotaan perlu ditangani melalui berbagai kebijakan strategi, perencanaan, dan perancangan yang terpadu dilaksanakan secara di masa yang akan datang. Direktorat Jenderal Cipta Karya mengeluarkan program yang dilakukan untuk mengentaskan kekumuhan yang ada di kota Jakarta sesuai dengan amanat UU No 17/2007 tentang RPJPN kota tanpa pemukiman kumuh yang melahirkan RPJMN tentang permukiman layak huni dan berkelanjutan yang disebut sebagai Kota Tanpa Kumuh (KOTAKU). Yang merupakan program 100-0-100, program ini dilaksanakan untuk mencapai sasaran 20152019 adalah 100\% akses air minum, agar kebutuhan dasar masyarakat terpenuhi, 0\% kawasan kumuh dilakukan pemenuhan kebutuhan hunian dilengkapi dengan prasarana dan sarana umum, dan juga $100 \%$ sanitasi seperti persampahan, limbah, dan drainase lingkungan.

Program KOTAKU adalah platform kolaborasi antara pemerintah pusat, pemerintah daerah, swasta, dan masyarakat, dimana masing - masing pemangku kepentingan memiliki perannya. Terkait prinsip KOTAKU ini tentunya berbentuk kolaborasi, dimana KOTAKU mempunyai 9 prinsip dasar dalam pelaksanaan programnya, salah satunya yaitu prinsip partisipatif yang dilakukan dengan memadukan perencanaan dari atas (top-down) dan dari bawah (bottom-up) sehingga perencanaan di tingkat masyarakat akan menjadi bagian tidak terpisahkan dari perencanaan yang lebih makro.

Kenyataannya, prinsip partisipatif ini belum dapat di terapkan atau terealisasikan secara baik. Program ini masih lebih didominasi perencanaan top-down. Seperti yang terjadi pada objek penelitian ini, yaitu di Kampung Rawa Barat, Kelurahan Kebon Jeruk, Kecamatan Kebon Jeruk, Jakarta Barat pada penanganan di RT 15/16 RW 04, pelaksanaan program KOTAKU ini berdasarkan luasan kumuhnya yang ditangani oleh pemerintah provinsi. Akan tetapi awal masuknya program KOTAKU, pemerintah tidak memberi sosialiasi terlebih dahulu kepada masyarakat. Pemerintah provinsi secara langsung mengambil alih untuk penanganannya. Untuk di RT 15/16 RW 04 sendiri, pelaksanaan programnya dilakukan oleh warganya sendiri tetapi yang kebanyakan terlibat adalah warga yang tergabung dalam kelembagaan di tingkat masyarakat sedangkan masyarakat lain yang tidak termasuk di dalam kelembagaan tersebut tidak diajak untuk terlibat dan ada juga yang sudah diajak untuk terlibat malah tidak ada minatnya. Berdasarkan hal diceritakan tersebut, maka penulis melakukan kajian dengan judul "Studi Tingkat Partisipasi Masyarakat Dalam Pelaksanaan Program KOTAKU" di Kampung Rawa Barat, Kelurahan Kebon Jeruk. 
Kota Jakarta Barat memiliki luas wilayah $129,54 \mathrm{~km}^{2}$, dengan jumlah penduduk pada tahun 2019 sebanyak 2.589.933 jiwa. Sehingga memiliki kepadatan penduduk 19.993 orang/km2. Kampung Rawa Barat adalah salah satu kampung yang berada di Kelurahan Kebon Jeruk, Kecamatan Kebon Jeruk Jakarta Barat. Sebelumnya kampung ini dikenal sebagai kampung Rawa namun satu tahun belakangan ini terjadi pemekaran menjadi Rawa Barat dan Rawa Timur, Rawa Barat sendiri awalnya hanya memiliki satu RT yaitu RT 02 /RW 04 kemudian terjadi pemekaran menjadi dua RT yaitu RT 15 dan RT 16 dengan kondisi kawasan yang tergolong padat, peningkatan penduduk meningkat setiap tahunnya sehingga tidak sesuai dengan arahan RTRW Kota Jakarta Barat. Dengan adanya permasalahan peningkatan jumlah penduduk membuat permasalahan yang muncul di perkotaan. Permasalahan diantaranya yaitu rendahnya kualitas lingkungan (kampung kumuh), kesenjangan sosial, yang meningkat menjadi pekerjaan rumah yang besar bagi hampir setiap kota besar terutama di kota Jakarta yang merupakan pusat terbesar di Indonesia. Untuk itu dari penjelasan diatas mengenai program yang telah di implementasikan oleh pemerintah terhadap penanganan permasalahan perumahan dan permukiman kumuh, serta kondisi dari kawasan permukiman kumuh yang masih terjadi khususnya di Kampung Rawa Barat, Kelurahan Kebon Jeruk, penulis tertarik untuk melakukan kajian lebih lanjut tentang penanganan permasalahan perumahan dan permukiman kumuh dan menuangkannya dalam penelitian yang berjudul Penerapan Program KOTAKU Dalam Mengatasi Kawasan Permukiman Kumuh di Kampung Rawa Barat, Kelurahan Kebon Jeruk, Kota Jakarta Barat.

\section{Rumusan Masalah}

Kampung Rawa barat, merupakan sebuah kampung yang kondisinya secara fisik kumuh, sehingga menimbulkan kerawanan terhadap penyakit maupun bencana kebakaran. Kemeterian Pekerjaan Umum dan Perumahan Rakyat, mempunyai Program Koata tanpa kumuh (KOTAKU), Program KOTAKU mensyaraktakan adanya partisipasi masyarakat pda rehabilitasi kampng kumuh. Adanya partisipasi masyarakat akan mewujudkan kampung yang sehat. Pada penelitian ini peneliti melakukan penelitian partisipasi masyarakat merubah kampung kumuh menjadi kampung sehat.

\section{Tujuan Penelitian}

Adapun tujuan yang diharapkan dalam penelitian, sebagai berikut :

1. Mengetahui tingkat kekumuhan kawasan Kampung Rawa Barat, Kelurahan Kebon Jeruk.

2. Mengetahui Partisipasi Masyarakat dalam penyelengaraan Program KOTAKU di Kampung Rawa Barat.

\section{KAJIAN LITERATUR}

\section{Identifikasi Kawasan Permukiman Kumuh}

Identifikasi permasalahan kekumuhan dilakukan berdasarkan pertimbangan pengertian perumahan kumuh dan permukiman kumuh, persyaratan teknis sesuai ketentuan yang berlaku, serta standar pelayanan minimal yang dipersyaratkan secara nasional berdasarkan beberapa kriteria (Permen PUPR No. 2 Tahun 2016).

1. Kondisi Bangunan Gedung

a. Ketidakteraturan Bangunan (tidak sesuai RDTR dan RTBL)

b. Tingkat Kepadatan Bangunan (KDB dan KLB melebih ketentuan RDTR)

c. Ketidaksesuaian dengan Persyaratan teknis Bangunan (kesehatan prasarana umum, keselamatan bangunan, dll) 
2. Kondisi Jalan Lingkungan

a. Cakupan Pelayanan Jalan Lingkungan

b. Kualitas Permukaan Jalan Lingkungan

3. Kondisi Penyediaan Air Minum

a. Ketersediaan akses aman air minum

b. Tidak terpenuhinya kebutuhan air minum

4. Kondisi Drainase Lingkungan

a. Tidak mampu mengalirkan limpasan air

b. Ketidaktersediaan drainase

c. Ketidakterhubungan dengan sistem drainase kota

5. Kondisi Pengelolaan Air Limbah

a. Sistem pengelolaan air limbah tidak sesuai standar teknis

b. Prasarana dan sarana pengelolaan air limbah tidak sesuai dengan persyaratan teknis

6. Kondisi Pengelolaan Persampahan

a. Prasarana dan Sarana persampahan tidak sesuai dengan persyaratan teknis

b. Sistem pengelolaan persampahan yang tidak sesuai standar

c. Tidak terpelihara sarana dan prasarana pengelolaan persampahan

7. Kondisi Proteksi Kebakaran

a. Ketidaktersediaan prasarana proteksi kebakaran

b. Ketidaktersediaan sarana proteksi kebakaran

\section{Program Kota Tanpa Kumuh (KOTAKU)}

Kebijakan Program (Undang-Undang Dasar Tahun 1945 Pasal 28H Ayat 1 menyatakan bahwa : Setiap orang berhak untuk hidup sejahtera lahir dan batin, bertempat tinggal, dan mendapatkan lingkungan hidup yang baik dan sehat, serta berhak memperoleh pelayanan kesehatan. Ayat tersebut menunjukkan bahwa tinggal di sebuah hunian dengan lingkungan yang layak merupakan hak dasar yang harus dijamin pemenuhannya oleh Pemerintah sebagai penyelenggara negara. Selanjutnya Undang-Undang Nomor 1 Tahun 2011 tentang perumahan dan permukiman, menyatakan bahwa penanganan permukiman kumuh wajib dilakukan oleh Pemerintah, Pemerintah Daerah dan atau setiap orang. Berdasarkan amanah dari kedua Undang-Undang tersebut, maka pemerintah perlu melakukan upaya - upaya dan langkahlangkah untuk menggagas program-program dalam rangka penanganan kawasan permukiman dan meningkatkan kualitas permukiman terutama untuk pananganan dan peningkatan kualitas kawasan permukiman kumuh. Dari dasar aturan kebijakan diatas, Direktorat Jenderal Ditjen Cipta Karya (DJCK) menetapkan Surat Edaran Nomor: 40/SE/DC/2016 tentang Pedoman Pelaksanaan Program Kota Tanpa Kumuh (KOTAKU). Untuk itu, seluruh program di Kementerian PUPR khususnya pada Ditjen Cipta Karya, dalam kurun waktu 5 tahun (20152019) akan difokuskan untuk mewujudkan permukiman yang layak huni hingga tercapai 0 ha kumuh.

Partisipasi masyarakat terhadap pelaksanaan program KOTAKU dapat meliputi beberapa tahapan, diantaranya:

1. Partisipasi masyarakat dalam tahapan persiapan program, dimana keikutsertaan masyarakat dalam tahapan-tahapan program seperti mensosialisasikan program, menggalang komitmen dengan pemerintah daerah dan DPRD dan peduli terhadap pelaksanaan program KOTAKU di lingkungannya sangat diharapkan.

2. Partisipasi masyarakat dalam tahapan perencanaan program, dimana keikutsertaan masyarakat dalam menyusun perencanaan penanganan permukiman kumuh yang terintegrasi di lingkungannya sangat menentukan sinergisitas perencanaan dengan pembangunan kedepan. 
3. Partisipasi masyarakat dalam tahapan pelaksanaan program, dimana keikutsertaan masyarakat yang paling diharapakan mulai dalam menyusun anggaran setiap kegiatan yang direncanakan hingga mengusulkan ke Pemerintah pusat, provinsi dan daerah. Dan

4. Partisipasi masyarakat dalam tahapan keberlanjutan program, dimana pentingnya peran masyarakat dalam penguatan regulasi untuk tata kelola penanganan permukiman kumuh kedepan dan kepedulian masyarakat dalam memelihara pembangunan pada lingkungannya.

\section{METODE PENELITIAN}

Pada penelitian ini menggunakan Pendekatan Kuantitatif. Dalam pendekatan kuantitatif memusatkan perhatian kepada gejala yang mempunyai karakteristik tertentu didalam kehidupan manusia yang dinamakannya Variabel.

\section{Lokasi Penelitian}

Lokasi Objek Studi berada pada RT 15 dan RT 16 RW 04 di Kampung Rawa Barat, Kelurahan Kebon Jeruk, Kecamatan Kebon Jeruk, Jakarta Barat.

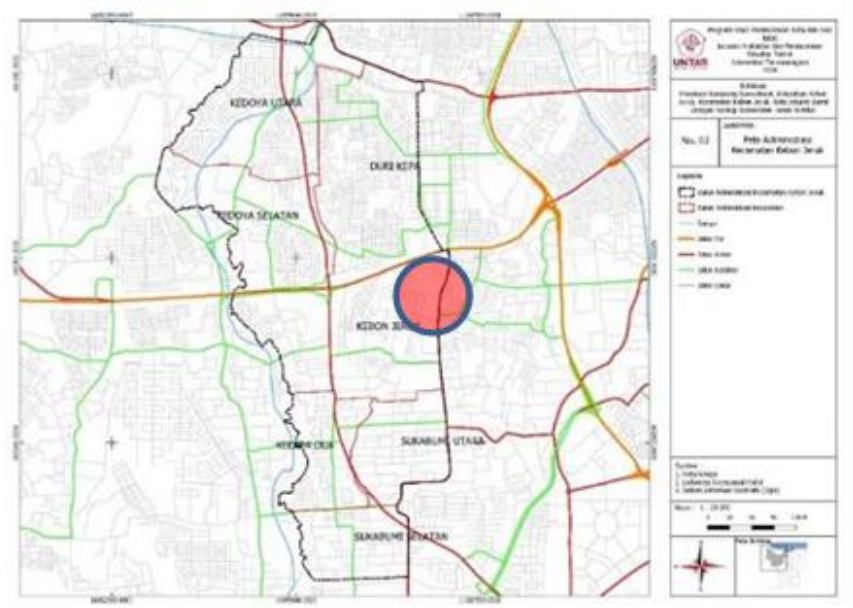

Gambar 1. Peta Lokasi Objek Studi Sumber : Google Maps

Populasi dan Sampling Populasi

Tabel 1. Jumlah data populasi dan sampel menurut kampung/titik kawasan kumuh

\begin{tabular}{|c|c|c|c|c|c|}
\hline No. & Lokasi Kumuh & Kecamatan & $\begin{array}{l}\text { Luas Kumuh } \\
\text { (Ha) }\end{array}$ & Jumlah KK & $\begin{array}{l}\text { Jumlah Sampel } \\
\text { (KK/Responden) }\end{array}$ \\
\hline 1 & RT 15 & Kebon Jeruk & \multirow[t]{2}{*}{3,7} & 316 & 44 \\
\hline \multirow[t]{2}{*}{2} & RT 16 & Kebon Jeruk & & 420 & 44 \\
\hline & & Total & & 736 & 88 \\
\hline
\end{tabular}

Sumber: Data Populasi Rumah Tangga, RW 04

Sampling

Perhitungannya :

$$
\begin{gathered}
n=\frac{736}{1+\left(736 \times 0,1^{2}\right)}=\frac{736}{1+(736 \times 0,01)}=\frac{736}{1+7,36} \\
=\frac{736}{8,36}=88,03 \text { maka dapat dibulatkan menjadi } 88
\end{gathered}
$$

Dari 88 sampel yang diambil merupakan unsur KK/responden lainnya, didistribusikan ke 1 kawasan permukiman kumuh tersebut. Jumlah sampel responden diambil berdasarkan Sampling Kuota. Jumlah populasi dan sampel penelitian dapat dilihat pada tabel 3.3 sebagai berikut: 
Keabsahan (validitas) hasil penelitian ditentukan oleh alat pengukuran (instrument) yang digunakan dan data yang diperoleh. Jika alat pengukuran alat variabel tersebut tidak reliable dan tidak absah, maka hasilnya tidak menggambarkan keadaan yang sesungguhnya. Untuk dapat diyakinkan bahwa data tersebut valid dan handal maka perlu dilakukan 2 (dua) pengujian yaitu Uji Validitas dan Uji Reliabilitas. Pengukuran validitas dan reliabilitas mutlak dilakukan, karena jika instrumen yang digunakan sudah tidak valid dan reliable maka dipastikan hasil penelitiannya pun tidak akan valid dan reliable. Instrumen yang telah dikembangkan disebar kepada responden penelitian, hasilnya dianalisis untuk mengetahui validitas instrument dan realibilitas instrument variabel setiap penelitian. Perhitungan matematis yang bisa memperoleh nilai koefisien korelasi validitas dan koefisien reliabilitas yang dilakukan dalam penelitian dengan menggunakan software SPSS for Windows.

Untuk menganalisis validitas, akan digunakan Uji Korelasi Pearson Product Moment. Tingkat kevalidan penelitian ini baiknya memperoleh hasil hitung $\geq 0.40$ sehingga membuktikan bahwa item tersebut dapat dikatakan valid. Dalam pengujian ini, terdapat 6 kriteria tingkat kevalidan, dapat dilihat pada tabel berikut:

Tabel 2. Interpretasi Koefisien Validitas

\begin{tabular}{cclc}
\hline No & Koefisien Validitas & \multicolumn{1}{c}{ Tingkat Validitas } & Keterangan \\
\hline 1 & $<0,00$ & Berkolerasi Negatif & Invalid \\
\hline 2 & $0.00-0,20$ & Berkolerasi Sangat Rendah & Invalid \\
\hline 3 & $0,21-0,40$ & Berkolerasi Rendah & Invalid \\
\hline 4 & $0,41-0,60$ & Berkolerasi Cukup & Valid \\
\hline 5 & $0,61-0,80$ & Berkolerasi Tinggi & Valid \\
\hline 6 & $0,81-1,00$ & Berkolerasi Sangat Tinggi & Valid \\
\hline
\end{tabular}

Sumber: Arikunto, 2006

Untuk menganalisis reliabilitas pengujian dalam penelitian ini digunakan metode Cronbach Alpha yang dapat menafsirkan korelasi antara skala yang dibuat dengan skala variabel yang ada. Akan dilihat nilai Alpha-Cronbach untuk reliabilitas keseluruhan item dalam satu variabel. Nilai tiap-tiap item sebaiknya $\geq 0.40$ sehingga membuktikan bahwa item tersebut dapat dikatakan punya reliabilitas konsistensi internal.

Tabel 3. Interpretasi Koefisien Realibilitas

\begin{tabular}{cccc}
\hline No & Koefisien Validitas & Tingkat Realibilitas & Keterangan \\
\hline 1 & $0.00-0,20$ & Reliabilitas Sangat Rendah & Unreliable \\
\hline 2 & $0,21-0,40$ & Reliabilitas Rendah & Unreliable \\
\hline 3 & $0,41-0,60$ & Reliabilitas Cukup & Reliable \\
\hline 4 & $0,61-0,80$ & Reliabilitas Tinggi & Reliable \\
\hline 5 & $0,91-1,00$ & Reliabilitas Sangat Tinggi & Reliable
\end{tabular}

Sumber: Arikunto, 2006

\section{Hasil Uji Validitasi dan Uji Realibilitas}

Uji Validitasi, Pengumpulan data kuesioner dari jawaban responden Kampung Rawa Barat menunjukkan bahwa hasil pengujian validitas terhadap pola partisipasi masyarakat dalam penyelenggaraan program KOTAKU di Kampung Rawa Barat dari 4 macam pertanyaan yang diujicobakan kepada 88 responden semuanya untuk Tahapan Persiapan dan Perencanaan Program dinyatakan Invalid karena $r \leq 0.40$. kemudian untuk Tahapan Pelaksanaan dan Keberlanjutan Program dinyatakan Valid berdasarkan nilai koofisien $r$ yang dihasilkan dari perhitungan secara matematis $r \geq 0.40$. 
Uji Realibilitas, Berdasarkan hasil analisis reliabilitas dapat diketahui bahawa alpha untuk variabel pola partisipasi masyarakat dalam penyelenggaraan program KOTAKU di Kampung Rawa Barat diperoleh nilai sebesar 0,821 yang berarti bahwa variabel tersebut dinyatakan reliabel.

\section{Pengumpulan Data}

Pengumpulan data dilakukan dengan cara :

1. Penyeberan Kuesioner kepada Penduduk Kampung Rawa Barat

2. Menggunakan Data yang sudah di publikasikan (BPS, ATR/BPN, Kelurahan Kebon Jeruk, dII)

\section{Analisis Data}

a. Analisis Kebijakan. Membuat kesesuaian peraturan Undang-Undang dan Dinas Pekerjaan Umum dan Perumahan Rakyat yang telah disahkan dengan kondisi eksisting serta melihat rencana pembangunan pada objek penelitian.

b. Analisis Lokasi. Mengidentifikasi potensi dan karakteristik lokasi tapak secara makro, serta aksesibilitas dan kemudahan pencapaiannya.

c. Analisis Karakteristik Masyarakat yang tinggal pada kawasan permukiman kumuh di Kampung Rawa Barat. Dengan cara mendeskripsikan karakter masyarakat responden terhadap faktor-faktor yang mempengaruhi partisipasi masyarakat berdasarkan teori yang dikemukakan oleh Slamet (1993), terdapat 6 jenis karakter yang menjadi tujuan analisis yaitu Jenis kelamin, Usia, Tingkat pendidikan, Tingkat penghasilan, dan mata pencaharian.

d. Analisis Kondisi Fisik Kawasan Permukiman Kumuh di Kampung Rawa Barat. Dengan cara mendeskripsikan permasalahan - permasalahan permukiman kumuh berkenaan dengan adanya kondisi fisik perumahan dan infrastruktur permukiman berdasarkan 7 aspek kekumuhan yang ada, meliputi : kondisi bangunan hunian, Jalan Lingkungan, Ketersediaan air minum/bersih, saluran drainase, akses air limbah rumah tangga/sanitasi, pengelolaan persampahan dan kondisi proteksi bencana kebakaran. Analisis tersebut selanjutnya disajikan dalam bentuk tabulasi dan gambar.

e. Analisis Tingkat Partisipasi masyarakat dalam penyelenggaraan program KOTAKU di Kampung Rawa Barat. Dengan cara mentabulasi data berdasarkan variabel - variabel dari kuesioner seluruh jawaban responden berdasarkan presentase dan pemberian skor terhadap setiap jenis kegiatan yang telah diamati, yaitu :

1. Tingkat partisipasi dalam tahap persiapan program :

Selalu ikut (61\%-100\%) diberi skor 3

Kadang - kadang ikut (31\% - 60\%) diberi skor 2

Tidak pernah ikut (1\%-30\%) diberi skor 1

2. Tingkat partisipasi dalam tahap perencanaan program KOTAKU :

selalu ikut (61\%-100\%) diberi skor 3

Kadang - kadang ikut (31\% - 60\%) diberi skor 2

Tidak pernah ikut (1\%-30\%) diberi skor 1

3. Tingkat partisipasi dalam tahap pelaksanaan program KOTAKU :

selalu ikut (61\%-100\%) diberi skor 3

Kadang - kadang ikut (31\% - 60\%) diberi skor 2

Tidak pernah ikut (1\%-30\%) diberi skor 1

4. Tingkat partisipasi dalam tahap keberlanjutan program KOTAKU :

selalu ikut (61\%-100\%) diberi skor 3

Kadang - kadang ikut (31\% - 60\%) diberi skor 2

Tidak pernah ikut (1\%-30\%) diberi skor 1 
Hasil dari perhitungan dari masing-masing jenis tahapan partisipasi responden masyarakat akan menentukan tingkatan partisipasi masyarakat dalam penyelenggaraan program KOTAKU di Kampung Rawa Barat yang dibedakan dalam 3 tingkatan partisipasi, yaitu:

Tabel 4. Interpretasi jenjang skor tingkat partisipasi masyarakat

\begin{tabular}{ccc}
\hline No & Hasil Nilai (skor) partisipasi & Pengukuran tingkat partisipasi \\
\hline 1 & $90-150$ & Rendah \\
\hline 2 & $151-210$ & Sedang \\
\hline 3 & $211-270$ & Tinggi \\
\hline
\end{tabular}

Sumber: diolah penulis, 2021

Untuk menentukan penelitian yang dapat dipercaya atau sahih ditentukan oleh alat pengukuran yang digunakan untuk mengukur variabel yang akan diteliti yaitu uji validitas dan uji relibilitas.

f. Analisis Tingkat Kekumuhan pada kawasan permukiman kumuh di Kampung Rawa Barat.

Tingkat kekumuhan yang akan dianalisis menggunakan data sekunder dari kondisi fisik objek studi berdasarkan 19 kriteria dari 7 aspek kekumuhan yang bersumber dari Data Numerik Baseline 100-0 - 100 kawasan permukiman kumuh Kampung Rawa Barat. Data Numerik Baseline selanjutnya diolah dan dilakukan perhitungan tingkat kekumuhan terhadap kawasan objek studi dengan mempedomani rumus perhitungan yang telah ditetapkan dalam Peraturan Menteri PUPR Nomor 2 Tahun 2016.

Setelah hasil perhitungan berdasarkan perumusan penentu Tingkat Kekumuhan Kawasan Permukiman yang dibedakan atas 3 klasifikasi berdasarkan 3 jenjang skor, sebagaimana dapat diperhatikan pada Tabel berikut:

Tabel 5. Interpretasi skor tingkat kekumuhan pada permukiman kumuh

\begin{tabular}{ccc}
\hline No & Internal (skor) & Klasifikasi Tingkat Kekumuhan \\
\hline 1 & $19-44$ & Ringan \\
\hline 2 & $45-70$ & Sedang \\
\hline 3 & $71-95$ & Berat
\end{tabular}

Sumber: data olahan berdasarkan pedoman Permen PUPR No.2 Tahun 2016

g. Analisis Tapak

Analisis Status Lahan. untuk mengetahui tapak di Kampung Rawa Barat, mulai dari legalitas lahan, penggunaan lahan, intensitas bangunan, dan nilai lahan.

h. Analisis Kebijakan

Penelitian penulis tentang penataan kawasan permukiman kumuh layak dilakukan agar menjamin hak penduduk kampung untuk menempati lingkungan yang lebih layak, sehat, aman, dan teratur. Selain itu juga, didalam UU juga menjelaskan jika terdapat dua bentuk penanganan permukiman kumuh yang dapat ditangani, salah satunya adalah pencegahan dan peningkatan kualitas. Yang dimana untuk tindakan pencegahan ditujukan untuk menghindari berkembangnya perumahan atau permukiman kumuh baru. Dilakukan berdasarkan kesesuaian terhadap perizinan (izin lokasi, penggunaan pemanfaatan tanah, dan izin mendirikan bangunan, standar teknis lainnya).

\section{Variabel Operasional Penelitian}

Berdasarkan variabel - variabel yang telah dijelaskan sebelumnya, variable selanjutnya dapat dijabarkan definisinya masing - masing melalui tabel dibawah ini, yaitu : 


\begin{tabular}{|c|c|c|c|c|}
\hline No & Variabel & Definisi & Indikator & Pengukuran \\
\hline 1 & $\begin{array}{l}\text { Kawasan } \\
\text { Kumuh }\end{array}$ & $\begin{array}{l}\text { Kawasan permukiman kumuh seluas } \\
3,7 \text { hektar tersebar pada Kampung } \\
\text { Rawa Barat RW 04, khususnya di RT } \\
15 \text { dan RT } 16 \text { berdasarkan daftar } \\
\text { Kampung Kumuh yang dirilis oleh } \\
\text { Pemprov DKI Jakarta. Selain } \\
\text { ditetapkan menjadi kawasan } \\
\text { permukiman kumuh, warganya } \\
\text { berasal bukan hanya dari Jakarta, } \\
\text { melainkan dari seluruh Indonesia. } \\
\text { setidaknya, sejak tahun } 2000 \text { sudah } \\
\text { dijadikan pemukiman oleh orang- } \\
\text { orang yang merantau. }\end{array}$ & 2 RT 1 RW & Input \\
\hline 2 & $\begin{array}{l}\text { Kondisi Fisik } \\
\text { Kawasan } \\
\text { Permukiman } \\
\text { Kumuh }\end{array}$ & $\begin{array}{l}\text { kondisi awal fisik kawasan } \\
\text { permukiman kumuh dinilai dari } \\
\text { kelayakn dan ketersediaan sarana } \\
\text { dan prasarana dasar permukiman } \\
\text { berdasarkan kriteria kekumuhan. }\end{array}$ & $\begin{array}{l}\text { - bangunan } \\
\text { - jalanan lingkungan } \\
\text { - air bersih } \\
\text { - air sanitasi } \\
\text { - pengelolaan sampah } \\
\text { - proteksi kebakaran }\end{array}$ & $\begin{array}{l}\text { Analisis } \\
\text { Deskriptif } \\
\text { Kualitatif }\end{array}$ \\
\hline 3 & $\begin{array}{l}\text { Program } \\
\text { KOTAKU }\end{array}$ & $\begin{array}{l}\text { program strategis yang digagas } \\
\text { Ditjen Cipta Karya Kementerian } \\
\text { PUPR dalam rangka percepatan } \\
\text { penanganan permukiman kumuh }\end{array}$ & $\begin{array}{l}\text { - bangunan } \\
\text { - jalanan lingkungan } \\
\text { - air bersih } \\
\text { - air sanitasi } \\
\text { - pengelolaan sampah } \\
\text { - proteksi kebakaran }\end{array}$ & Proses \\
\hline 4 & $\begin{array}{l}\text { Tingkat } \\
\text { Partisipasi } \\
\text { masyarakat }\end{array}$ & $\begin{array}{l}\text { proses identifikasi peran masyarakat } \\
\text { dalam penyelenggaraan program } \\
\text { KOTAKU terhadap penanganan } \\
\text { kawasan permukiman kumuh }\end{array}$ & $\begin{array}{ll}- & \text { Rendah } \\
\text { - } & \text { Sedang } \\
- & \text { Tinggi }\end{array}$ & $\begin{array}{l}\text { Analisis } \\
\text { Deskriptif, } \\
\text { kualitatif, } \\
\text { tabulasi, dan } \\
\text { pengukuran. }\end{array}$ \\
\hline 5 & $\begin{array}{l}\text { Masyarakat } \\
\text { responden }\end{array}$ & $\begin{array}{l}\text { rumah tangga yang menjadi } \\
\text { responden sample sebanyak } 88 \\
\text { Rumah Tangga pada kawasan } \\
\text { permukiman kumuh di Kampung } \\
\text { Rawa Barat. }\end{array}$ & Kuesioner & $\begin{array}{l}\text { Analisis } \\
\text { Deskriptif, } \\
\text { kualitatif, } \\
\text { tabulasi, dan } \\
\text { pengukuran. }\end{array}$ \\
\hline
\end{tabular}

Sumber: Data Olahan Penulis

\section{DISKUSI DAN HASIL} Profil Obyek Studi

Kampung Rawa Barat berlokasi di Kelurahan Kebon Jeruk, Kecamatan Kebon Jeruk, Jakarta Barat memiliki luas sebesar 3,7 Ha terdiri dari RT 15 RT 16 RW 04. Lahan yang awal mulanya hanya berupa kebun sayuran, berubah menjadi permukiman padat penduduk. Kampung yang berada tepat di badan kali, dan rumah lainnya memadat dalam satu tempat. Berdasarkan standar kampung kumuh DKI Jakarta, kondisi objek studi atau Kampung Rawa Barat merupakan permukiman yang kurang tertata dan kumuh. Selain itu sebagian warga atau penduduk Kampung Rawa Barat bukan hanya dari Jakarta, melainkan dari seluruh Indonesia, setidaknya sejak tahun 2000 sudah dijadikan permukiman oleh orang - orang yang merantau. 


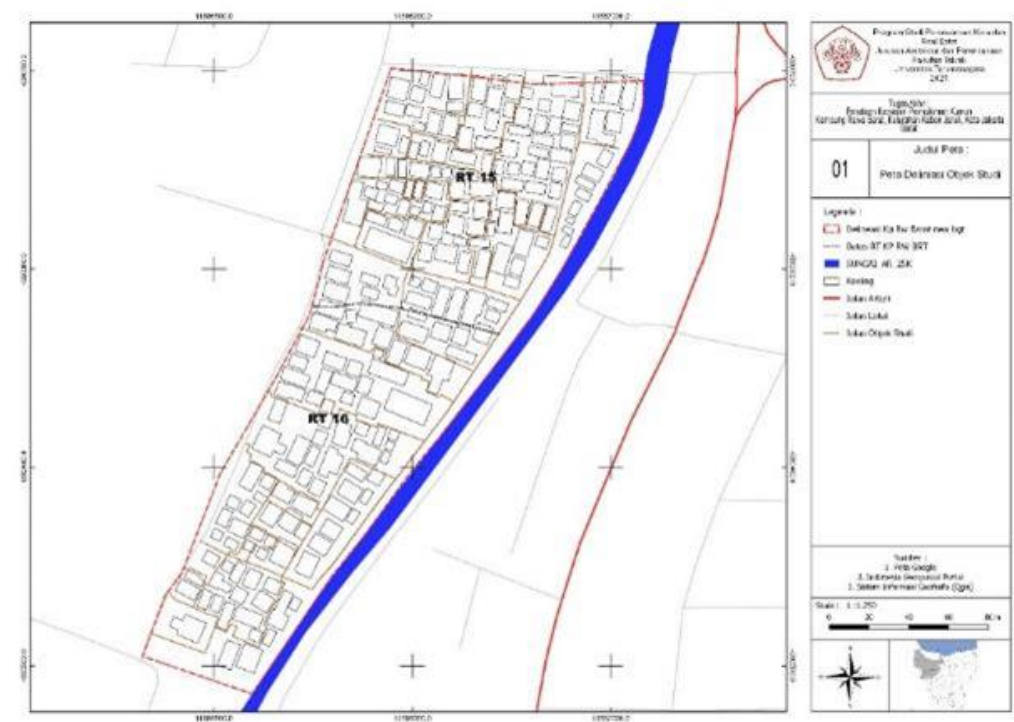

Gambar 2. Peta Delineasi Lokasi Objek Studi Kampung Rawa Barat RT 15 dan RT 16 RW 04 Sumber: Olahan Penulis, 2021

Batas - batas wilayah objek studi adalah sebagai berikut :

Utara : Jl. Budi I

Timur : : Jl. Budi Swadaya

Selatan : Il. Sang Timur

Barat : : Jl. Budi Swadaya, Jl. Karmel Raya

Tabel 7. Jumlah Penduduk, Luas Delineasi Kampung Kumuh dalam Kampung Rawa Barat Tahun 2020

\begin{tabular}{cccc}
\hline Kampung & Luas & Penduduk & Jumlah KK \\
\hline Kampung Rawa Barat & $3,7 \mathrm{Ha}$ & 736 & RT 15 316 KK \\
& & & RT 16 420 KK \\
\hline
\end{tabular}

Sumber: Olahan Penulis, 2021

\section{Kondisi Fisik Kampung Eksisting Rawa Barat RT 15 dan RT 16}
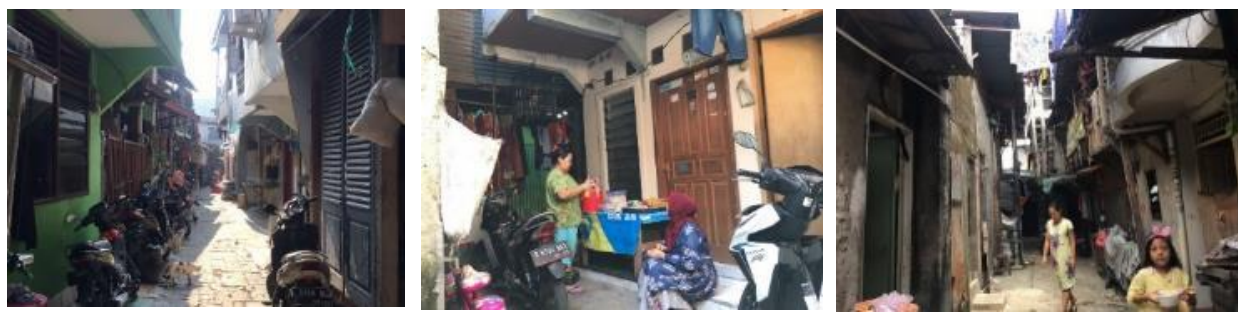

Gambar 3. Kepadatan Bangunan

Sumber: Dokumentasi Penulis, 2021
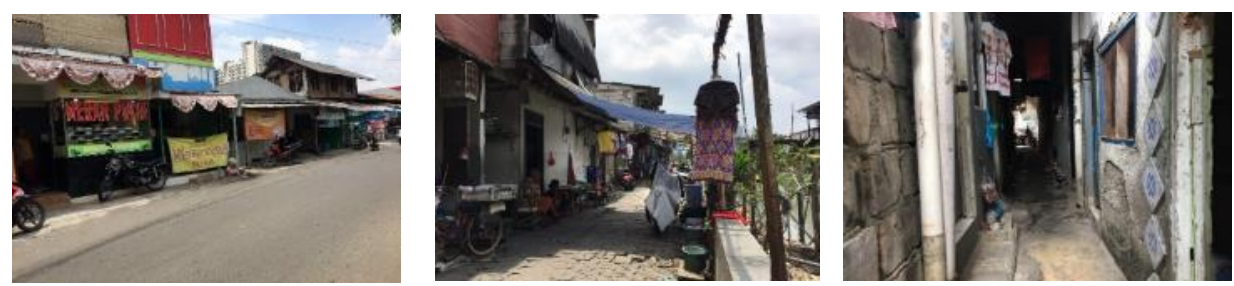

Gambar 4. Jaringan Jalan

Sumber: Dokumentasi Penulis, 2021 

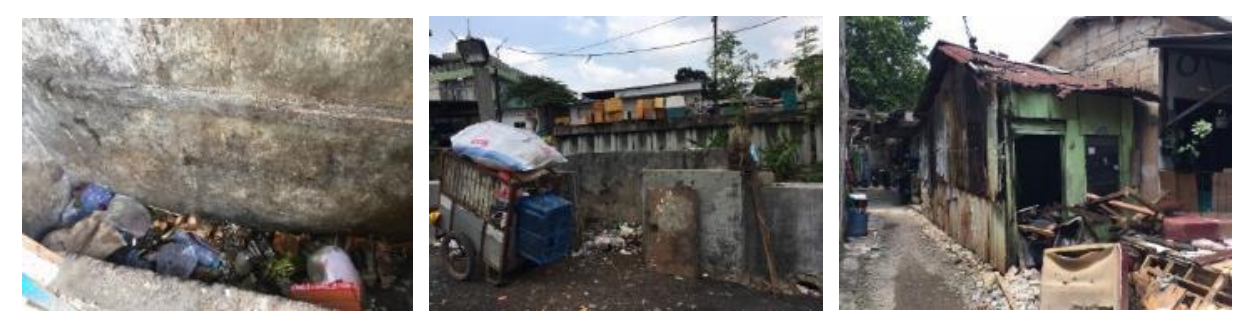

Gambar 5. Tempat Pembuangan Sampah

Sumber: Dokumentasi Penulis, 2021
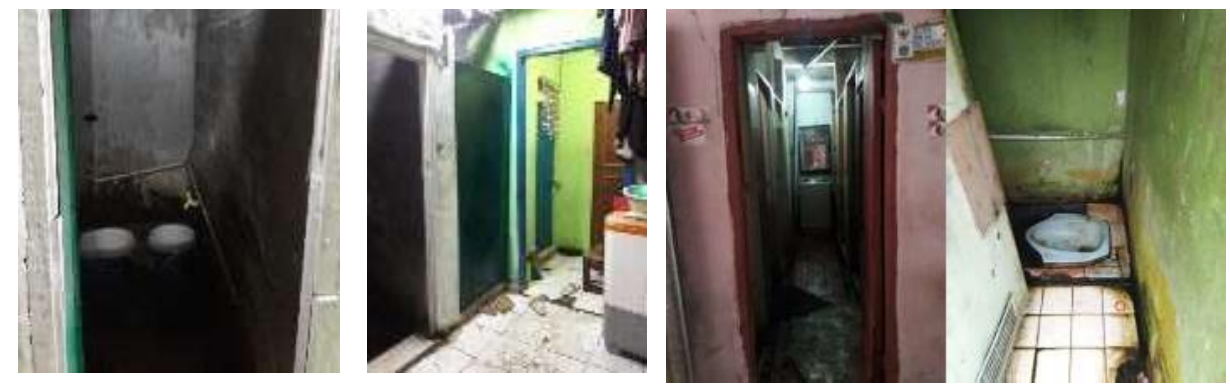

Gambar 6. Sanitase (MCK Umum dan Pribadi)

Sumber: Dokumentasi Penulis, 2021

Hasil wawancara penulis dengan Ketua RT 15 RW 04 yaitu bapak Dudi membahas mengenai Kondisi Masyarakat Kampung Rawa Barat :

" Kampung Rawa Barat ini dulu lahan yang awalnya berupa kebun sayuran, tepat berada di sempadan kali, sementara rumah yang lainnya memadat dalam satu tempat. Tanah di kampung Rawa Barat bukan kepemilikan warga, itu tanah bodong. Yang bikin kelihatan kumuh itu di pinggir kali, umumnya tak memiliki septiktank, alhasil hajat yang mereka buang akan langsung tersalurkan ke Kali Sekretaris, yang memisahkan antara Kp. Rawa Barat dengan Kampung Rawa Timur"

"Rencananya ingin membenahi rumah dibantara kali itu agar bisa diminum, tetapi harus ada instruksi ahli kota langsung agar bisa dipindah. Lalu rata-rata warga yang tinggal di pinggir tidak memiliki KIT DKI Jakarta dan kebanyakan pedagang dari Padang yang berdagang di Tanah Abang, Mangga Dua dan di Cempaka Mas. Sudah berulang kali mengingatkan warga di pinggir kali untuk membenahi rumahnya agar terlihat rapi namun tak juga membuahkan hasil. Secara umum kondisi saluran PDAM, penampungan air dan pipa sumur bor dalam keadaan baik, warga Kampung kita sendiri menggunakan PDAM atau sumur bor untuk pemenuhan kebutuhan air bersih. Tidak ada permasalahan air bersih di Kampung Rawa Barat, semua warga tercukupi akan kebutuhan air bersih. Selain itu Kampung Rawa Barat tidak termasuk dalam Data Daerah Rawan Banjir Provinsi DKI Jakarta"

Hasil wawancara penulis dengan Ketua RT 15 RW 04 yaitu bapak Dudi membahas mengenai Program Kerja KOTAKU di Kampung Rawa Barat :

Program KOTAKU merupakan program lanjutan dari Community Action Plan, mengenai Peningkatan Kualitas Kawasan Permukiman Kumuh, menurut bapak Dudi pelaksanaan program CAP kemarin belum dapat berjalan sepenuhnya sesuai program kerja yang telah disusun, sebagaimana pernyataan beliau berikut ini : 
"Untuk pelaksanaan yang sesuai dengan program kerja yang di susun memang sepenuhnya belum bisa terlaksana dengan baik. Karena ya itu mbak kita memang gak bisa memprediksi semua berhasil juga kan, sudah diusahakan semaksimal mungkin. Ada beberapa program yang sudah terlaksana ya kayak pelatihan-pelatihan, pembangunan dan perbaikan sarana prasarana juga (Penerangan Jalan Umum dan Tiang Listrik). Untuk pelaksanaan program meskipun terrdapat beberapa program belum terlaksana, tapi banyak juga program yang terlaksana bahkan bisa berkelanjutan sampai sekarang yang bisa di coba dengan rencana mbak nya yang mau meneliti program KOTAKU."

Partisipasi dan respon masyarakat terhadap program KOTAKU sangat mempengaruhi pelaksanaan program kerja KOTAKU. Kurangnya partisipasi masyarakat dapat menghambat pelaksanaan program KOTAKU dan tidak dapat mencapai tujuan yang telah ditentukan. Menurut wawancara peneliti dengan Bapak Dudi, beliau menyatakan bahwa masyarakat aktif berpartisipasi dalam setiap pelaksanaan program. Sebagaimana pernyataan berikut ini :

\begin{abstract}
"Alhamdulillah nya partisipasi masyarakat baik mbak, ya saling membantu setiap kegiatan. Karena kita memang mengajak masyarakat untuk ikut serta. Tapi ya ada juga yang tidak ikut, pasti ada yang seperti itu mbak. Masalahnya memang mereka belum tau atau kadang juga karena kesibukkan mereka masing-masing. Ya intinya sejauh ini masyarakat aktif."
\end{abstract}

\title{
Kondisi Fisik Kawasan Permukiman Kumuh (Fisik Bangunan, Jaringan jalan, Air Minum, Drainase, Air Limah Pengelolaan Sampah)
}

Kondisi Fisik Bangunan, Dengan jumlah bangunan yang ada sebanyak 219 unit, dengan kriteria: Sebanyak 164 unit bangunan (74,9\%) dikategorikan bangunan yang tidak teratur, dinilai dari tidak memenuhi ketentuan dalam RDTR baik bentuk, besaran, dan tampilan. Tingkat kepadatan bangunan rata-rata yaitu 164 unit/ha seluruh kawasan permukiman kumuh. Dan juga dikategorikan bangunan yang kualitasnya kurang sesuai dengan persyaratan teknis, dinilai dari bangunan kurang layak huni sebanyak 164 bangunan unit/ha (74,9\%) dimana dari segi kebutuhan keamanan maupun keselamatan bagi penghuninya, antara lain dilihat dari lantai, dinding, dana tap dari suatu rumah tinggal yang sehat.

Kondisi Jaringan Jalan, permasalahan jalan di kawasan permukiman kumuh Kampung Rawa Barat menunjukkan indikasi sebagian dari lokasi perumahan dan permukiman terlayani dengan jalan lingkungan tetapi juga masih banyak jalan dengan kondisi tidak ada rabat beton (permukaan jalan tanah), kondisi jalan yang sempit, jalan rusak diakibatkan tidak tersedianya jaringan drainase yang tidak berfungsi, sehingga beberapa area tergenang pada badan jalan.

Kondisi Penyediaan Air Bersih/Minum, permasalahan air bersih/minum di kawasan permukiman kumuh Kampung Rawa Barat menunjukkan sudah memadainya pelayanan air bersih sebagai air konsumsi kepada masyarakat penduduk setempat sudah memiliki akses terhadap sarana dan prasarana air bersih yang aman dan cukup.

Kondisi Jaringan Drainase, permasalahan jaringan drainase dikawasan permukiman kumuh Kampung Rawa Barat menunjukkan indikasi kondisi saluran drainase di sebagian wilayah kawasan kumuh Kampung Rawa Barat dalam kondisi kurang terawat, disebabkan penyumbatam sampah, sehingga mengalami penyempitan yang mengakibatkan saluran tidak berfungsi secara maksimal. Kemudian beberapa titik lainnya ada yang belum memiliki saluran drainase sehingga mengakibatkan terjadi genangan pada saat turun hujan, dan tingkat kesadaran warga yang masih membiarkan saluran mengalami penyumbatan. 
Kondisi Pengelolaan Air Limbah, permasalahan air limbah KK di kawasan kumuh Kampung Rawa Barat terindikasi tingkat kesadaran masyarakat yang relatif rendah dengan menggunakan jamban keluarga sebagai sarana pembuangan limbah, sehingga menyebabkan banyaknya masyarakat yang memanfaatkan alam sebagai tempat pembuangan limbah rumah tangga yang sangat berpotensi terjadinya pencemaran pada lingkungan sekitar.

Kondisi Pengelolaan Persampahan, kondisi eksisting pengelolaan persampahan pada Kampung Rawa Barat, dari total keseluruhan KK yaitu sejumlah 736 KK dikategorikan tidak memiliki sarana dan prasarana persampahan yang sesuai dengan persyaratan teknis, hal ini ditandai dengan tempat pembuangan sampah dan belum tersedianya tempat pembuangan sampah (TPS) pada lingkungan, sehingga rumah tangga masih membuang sampah sembarangan dan juga membakarnya.

\section{Tingkat Kekumuhan Pada Kawasan Permukiman Kumuh}

Tabel 8. Perhitungan tingkat kekumuhan kawasan Kampung Rawa Barat

\begin{tabular}{|c|c|c|c|}
\hline No & Aspek kekumuhan & Nilai kekumuhan & Klasifikasi \\
\hline 1 & Bangunan Gedung & $3+3+3$ & \multirow{4}{*}{$\begin{array}{c}\text { Interval (skor) } \\
19-44\end{array}$} \\
\hline 2 & Jalan Lingkungan & $1+5$ & \\
\hline 3 & Drainase Lingkungan & $1+5+1+1+1$ & \\
\hline 5 & Pengelolaan Persampahan & $5+5+5$ & \\
\hline & Jumlah & 39 & Ringan \\
\hline
\end{tabular}

Sumber: Hasil Olahan Penulis, 2021

\section{Tingkat Partisipasi Masyarakat Dalam Penyelenggaraan KOTAKU}

Hasil Analisis terhadap rata-rata tingkat partisipasi masyarakat dalam penyelenggaraan program KOTAKU mulai dari keikutsertaan masyarakat dalam Tahapan Persiapan, Perencanaan, Pelaksanaan, Keberlanjutan Program di Kampung Rawa Barat menunjukkan ratarata pada tingkat partisipasi sedang, dimana nilai/skor yang dihasilkan yaitu sebesar 199,5, yang berada pada interval dengan jenjang skor antara 151-210.

\section{KESIMPULAN DAN SARAN}

Dari hasil penelitian terhadap rumusan masalah yang telah diuraikan pada BAB IV, yang dapat ditarik kesimpulannya dari pelaksanaan program KOTAKU pada kawasan permukiman kumuh di Kampung Rawa Barat, yaitu Kondisi Fisik kawasan pada awal pelaksanaan program KOTAKU menunjukkan indikasi permasalahan :

a. Pada aspek perumahan dan bangunan hunian masih banyak menunjukkan banyaknya masyarakat yang menghuni rumah kurang layak dari konstruksi bangunan maupun letak bangunanya yang tidak aman bagi penghuni seperti berada di bantaran sungai.

b. Pada aspek jalan lingkungan masih terdapat permukiman tidak terlayani dengan jalan lingkungan, permukaan jalan tanah, jalan atau gang sempit, serta banyaknya jalan rusak diakibatkan oleh tidak tersedianya jaringan drainase sehingga menyebabkan badan jalan yang kadang tergenang.

c. Pada aspek jaringan drainase sebagian besar wilayah kawasan kumuh dalam kondisi rusak, dan beberapa jalan atau gang di Kampung Rawa Barat ada yang belum memiliki saluran drainase.

d. Pada aspek akses air limbah per KK, relatif masih rendah karena pembuangan dari MCK pribadi dan umum langsung dibuang atau tersalurakannya ke sungai dikarenakan tidak memiliki septiktank.

e. Pada aspek askes pengelolaan persampahan, keseluruhan rumah tangga yang berada pada Kampung Rawa Barat dikategorikan sudah memiliki sarana dan prasarana 
persampahan, akan tetapi tidak sesuai dengan persyaratan teknis sehingga masih banyak dari beberapa rumah tangga yang ada membuang sampah sembarangan atau membakarnya.

Tingkat Kekumuhan pada kawasan permukiman di Kampung Rawa Barat menunjukkan ratarata pada tingkat kekumuhan Ringan, yang dimana hasil perhitungan dari perumusan 6 aspek kondisi sarana dan prasarana kumuh memperoleh nilai sebesar 31, berada pada interval dengan jenjang skor antara 19-44. Tingkat Partisipasi Masyarakat dalam penyelenggaraan program KOTAKU, mulai dari keikutsertaan masyarakat atau warga dalam tahapan persiapan, perencanaan program di Kampung Rawa Barat menunjukkan rata-rata pada tingkat partisiapsi sedang, dimana nilai/skor yang dihasilkan sebesar 186 yang berada pada interval dengan jenjang skor antara 151-210. Hasil Uji Validitas menunjukkan bahwa hasil pengujian terhadap pola partisipasi masyarakat dalam penyelenggaraan program KOTAKU di Kampung Rawa Barat dari 4 macam pertanyaan yang diujicobakan kepada 88 responden untuk Tahapan Persiapan,Perencanaan Program dinyatakan Invalid karena $r \leq 0.40$. Kemudian untuk Tahapan Pelaksanaan dan Keberlanjutan Program dinyatakan Valid berdasarkan nilai koofisien $r$ yang dihasilkan dari perhitungan secara matematis $r \geq 0.40$. Hasil Uji Realibiltas menunjukkan bahwa alpha untuk variabel pola partisipasi masyarakat dalam penyelenggaraan program KOTAKU di Kampung Rawa Barat diperoleh nilai sebesar 0,821 yang berarti bahwa variabel tersebut dinyatakan reliabel.

\section{Saran}

Terdapat 2 saran guna mendukung dan melanjutkan program penanganan permukiman kumuh, yaitu :

1. Kepada Masyarakat, Khususnya kepada warga atau masyarakat yang tinggal di kawasan permukiman kumuh agar lebih ditingkatkan intensif untuk memperhatikan dan menjaga lingkungan permukimannya dari seluruh aspek yang dapat menimbulkan atau dapat menjadi sebabnya kekumuhan, serta memelihara sarana dan prasarana yang telah dibangun cukup baik oleh program KOTAKU maupun oleh Pemerintah agar dapat bermanfaat secara berkelanjutan sebagai kebutuhan dasar dari masyarakat.

2. Kepada Pemerintah Kota, Kebijakan pembangunan yang mengarah pada penanganan permukiman kumuh yang tertuliskan di dalam RPJMD agar dapat dievaluasi apakah telah seluruhnya dilaksanakan, terutama yang berkaitan dengan visi dan misi pembangunan rumah layak huni bagi masyarakat kurang mampu, serta program pembangunan permukiman lainnya. Untuk penanganan kawasan permukiman kumuh yang sebagaimana telah dilaksanakan oleh program KOTAKU sekiranya dapat kita dukung terus, terutama dalam rangka menyelesaikan permasalahan-permasalahan yang ada di kampung Rawa Barat, yaitu permasalahan sarana dan prasarana yang masih terjadi.

\section{REFERENSI}

Adina, S. (2010). Kajian Karakteristik Pemukim Kumuh Dan Liar Di Perkotaan Studi Kasus : Kelurahan Tegal Sari Mandala II Kecamatan Medan Denai Kota Medan. (Tesis). Universitas Sumatera Utara. Program Pascasarjana

Amelia, I. (2017). Analisis Faktor-faktor Yang Mempengaruhi Partisipasi Masyarakat Dalam Keberhasilan Program Kota Tanpa Kumuh/ KOTAKU (Studi Kasus di Kelurahan Kebon dalem Kota Cilegon dan Kelurahan Lontar Baru Kota Serang Provinsi Banten. (Tesis). Universitas Sumatera Utara. Program Pascasarjana

Anggara, V. (2018). Analisis Tingkat Kekumuhan dan Strategi Penanganan Kawasan Permukiman Kumuh di Kecamatan Tanjung Beringin Kabupaten Serdang Bedagai. (Tesis). Universitas Sumatera Utara. Program Pascasarjana 
Anthony J. Catanese dan James C. Snyder. (1992). Perencanaan Kota Edisi Kedua. Jakarta:Erlangga.

Bintoro T., (1982). Perencanaan Pembangunan. Jakarta:PT.Gunung Agung.

BPS. Kecamatan Kebon Jeruk Dalam Angka Tahun 2018

Bhumi ATR/BPN, https://bhumi.atrbpn.go.id/ Diakses pada 07 April 2021 jam 14.08 WIB.

Gregory H. W. (1993). Strategic Benchmarking. Jakarta:PT Gramedia Pustaka Utama.

Handbook "Program Kota Tanpa Kumuh (KOTAKU)"

Komarudin. (1997). Menelusuri Pembangunan Perumahan dan Permukiman. Penerbit Yayasan Real Estate Indonesia. Jakarta

Republik Indonesia. Peraturan Menteri Pekerjaan Umum dan Perumahan Rakyat Nomor 2 Tahun 2016 tentang Peningkatan Kualitas Terhadap Perumahan Kumuh dan Permukiman Kumuh.

Republik Indonesia. Peraturan Presiden Nomor 2 Tahun 2015 tentang Rencana Pembangunan Jangka Menengah Nasional Periode Tahun 2015 - 2019.

Republik Indonesia. Undang-Undang Nomor 1 Tahun 2011 tentang Perumahandan Kawasan Permukiman.

Rindarjono, G. (2017). Slum. Kajian Permukiman Kumuh Dalam Perspertif Spasial. Penerbit Media Perkasa. Yogyakarta.

Sinulingga. (2005). Pembangunan Kota, Tinjauan Regional dan Lokal, Penerbit Pustaka Sinar Harapan. Jakarta

Studies, R. C. (2018). DKI Jakarta: Rujak Centre for Urban Studies.

Surat Edaran Direktorat Jenderal Cipta Karya Kementrian Pekerjaan Umum dan Perumahan Rakyat Nomor: 40/SE/DC/2016. Tentang Pedoman Umum Program Kota Tanpa Kumuh.

Kriteria Program Penataan Kampung Kumuh dari data BPS 2017. https://Megapolitan.kompas.com

Panduan Identifikasi Kawasan Permukiman Kumuh. Ciptakarya.pu.go.id. [diakses 29 Maret 2021].

https://mediaindonesia.com/megapolitan/335648/belasan-kampung-kumuh-bakal-ditata. Diakses tanggal 15 Agustus 2020 pukul 10.00 WIB

https://data.jakarta.go.id/ Diakses pada 02 Februari 2021 jam 17.16 WIB. 
